\title{
Thermophotovoltaic systems for achieving high-solar-fraction hybrid solar-biomass power generation
}

\author{
CM Iftekhar Hussain \\ Technological University Dublin, CMIftekhar.Hussain@TUDublin.ie \\ Aidan Duffy \\ Technological University Dublin, aidan.duffy@tudublin.ie \\ Brian Norton \\ Technological University Dublin, brian.norton@tudublin.ie
}

Follow this and additional works at: https://arrow.tudublin.ie/dubenart

Part of the Environmental Engineering Commons, Operations Research, Systems Engineering and Industrial Engineering Commons, and the Other Civil and Environmental Engineering Commons

\section{Recommended Citation}

C.M. Iftekhar Hussain, Aidan Duffy, Brian Norton, Thermophotovoltaic systems for achieving high-solarfraction hybrid solar-biomass power generation, Applied Energy, Volume 259, 2020, 114181, ISSN 0306-2619, https://doi.org/10.1016/j.apenergy.2019.114181. (https://www.sciencedirect.com/science/ article/pii/S0306261919318689)

This Article is brought to you for free and open access by the Dublin Energy Lab at ARROW@TU Dublin. It has been accepted for inclusion in Articles by an authorized administrator of ARROW@TU Dublin. For more information, please contact arrow.admin@tudublin.ie, aisling.coyne@tudublin.ie,gerard.connolly@tudublin.ie. Funder: TU Dublin; Science Foundation Ireland

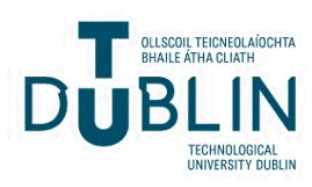




\title{
Thermophotovoltaic systems for achieving high-solar-fraction hybrid solar- biomass power generation
}

\author{
C.M. Iftekhar Hussain ${ }^{\mathrm{a}, *}$, Aidan Duffy ${ }^{\mathrm{a}, \mathrm{b}}$, Brian Norton ${ }^{\mathrm{a}, \mathrm{b}}$ \\ ${ }^{a}$ Dublin Energy Lab, Technological University Dublin, Grangegorman, Dublin 7, Ireland \\ ${ }^{\mathrm{b}}$ MaREI, the SFI Research Centre for Energy, Climate and Marine, Ireland
}

\section{H I G H L I G H T S}

- A new concept for hybrid solar-biomass thermophotovoltaic is implemented in TRNSYS simulation environment.

- TPV algorithm is developed and analysed to compare and validate with related previous work.

- Validated TPV algorithm is simulated for two system configurations to evaluate their output parameters.

- Results show; a TPV system could recover surplus thermal energy gained from CSP power plant at mid-days.

\section{A R T I C L E I N F O}

\section{Keywords:}

Thermophotovoltaic

Spectral control

Absorber/Emitter

Hybrid STPV

\begin{abstract}
A B S T R A C T
Medium operating temperature hybrid solar-biomass TPV power plant design requires complex integration of multiple high temperature processes with low band-gap TPV cells. A $0.72 \mathrm{eV}$ band-gap GaSb TPV cell has been used in thermophotovoltaic (TPV) systems operating at temperatures above $1400{ }^{\circ} \mathrm{C}$. Low band-gap TPV cells, such as InGaAs $\left(E_{g}=0.55 \mathrm{eV}\right)$ and $\operatorname{InAs}\left(E_{g}=0.36 \mathrm{eV}\right)$ could enable a TPV system to operate optimally at temperatures $\approx 1000{ }^{\circ} \mathrm{C}$. To examine this, two hybrid solar-biomass TPV system configurations are studied using TRNSYS simulation that incorporates a new algorithm for TPV. It is found that in a high solar fraction CSP power plant, a TPV system could recover surplus thermal energy gained from solar energy at mid-days that would otherwise be unused.
\end{abstract}

\section{Introduction}

The key components of a thermophotovoltaic (TPV) device are (i) radiative heat energy source (ii) absorber, (iii) emitter and (iv) TPV cell [1]. In a solar TPV (STPV) system, the absorber absorbs solar energy [2]. On the obverse of the absorber with a direct conductive contact is an emitter surface, emitting a thermal radiation spectrum [3]. Photons emitted from the emitter are incident on, and absorbed by the TPV cell to generate electricity $[4,5]$. TPV can be used in system applications such as (i) stand-alone solar [6], (ii) hybrid solar energy with secondary high temperature heat source [7], or (iii) in a stand-alone high temperature process $[8,9]$. A hybrid solar-biomass TPV power generation system flow diagram is shown in Fig. 1.

A particular TPV cell absorbs a specific emission spectrum to produce electricity $[10,11]$. To allow photons with energy in a TPV cell band-gap to be emitted from an emitter while restricting photons with sub-band-gap energy $[12,13]$ requires (i) a spectrally matched emitter attached to a high temperature heat source, or (ii) a spectral control filter. Unutilized photons radiated from the emitter increase TPV cell temperature, reducing its efficiency [14,15]. High conversion efficiency ensures that a TPV maintains constant rated power output [16]. At a specific temperature, different TPV cells produce different electric power outputs with different conversion efficiencies [17,18]. Determining an appropriate thermal energy emission wavelength is essential for successful TPV device operation $[19,20]$, but has, to date, been obtained by trial-and-error [21,22]. Simulation is used in this study for analysing this for both stand-alone and hybrid TPV systems. Previous studies have examined conventional CSP-biomass Rankine cycle power plant simulation using different TRNSYS libraries [23,24]. TPV power plants have not been previously simulated using TRNSYS as there was no TPV component in the TRNSYS library.

\section{Methodology}

A new TPV algorithm has been developed in TRNSYS 17 that enables examination of the technical characteristics of hybrid

\footnotetext{
* Corresponding author.
} 


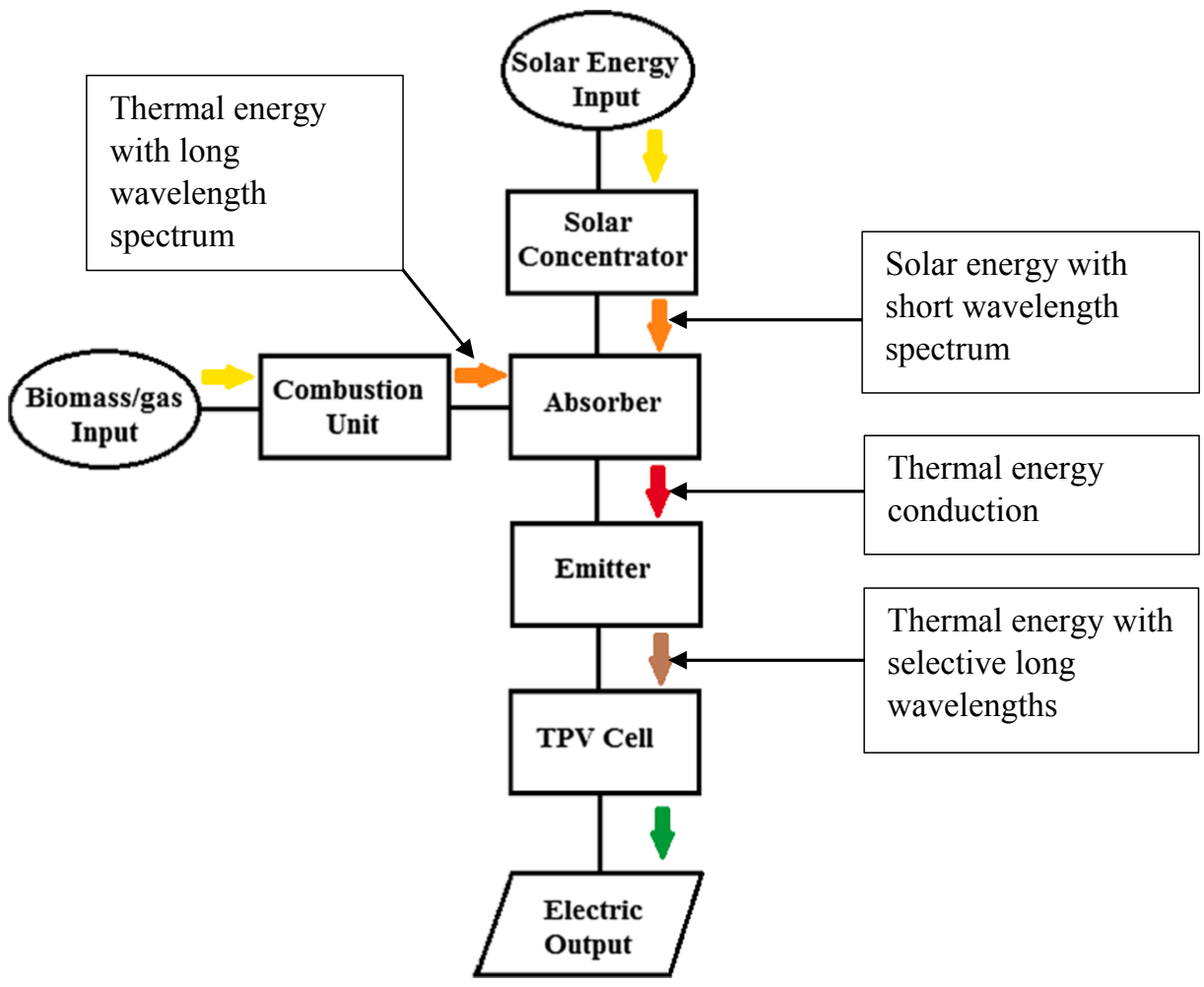

Fig. 1. Hybrid solar-biomass TPV system.

solar-biomass TPV power plant. TRNSYS 17 simulation software enables new system components to be introduced by:

(i) writing a new mathematical algorithm in a TRNSYS equation box to connect to existing TENSYS component $[25,26]$.

(ii) interfacing TRNSYS with new component developed in an external program $[27,28]$.

(iii) developing a new TRNSYS component $[29,30]$.

In this work, an InGaAsSb/InAsSbP TPV cell with an energy bandgap $\mathrm{E}_{\mathrm{g}}=0.55 \mathrm{eV}$ is used for all TPV system simulations. The TPV algorithm is written in the equation box "Type TPV" to connect to the solar central receiver component in the Solar Thermal Electric Component (STEC) library to obtain the thermal energy gained from solar energy conversion. The STEC library includes model for Rankine cycles, central receiver and heliostat fields and thermal energy storage systems [31,32]. This work used Rankine cycle, central receiver systems and Brayton cycle sub-libraries for simulating TPV power generation systems. Simulated TPV systems are;

(i) TPV Model-1: Stand-alone TPV configuration,

(ii) TPV Model-2: Hybrid solar-biomass with TPV system,

(iii) TPV Model-3: TPV retrofitted into a central receiver tower in a hybrid solar- biomass power plant.

Block diagrams of TPV system models are presented in Fig. 2. TPV Model-1 simulation results are verified through a validated analytical TPV model. TPV Model-1 is simulated at three different operating temperatures (i) $1000{ }^{\circ} \mathrm{C}$, (ii) $1200{ }^{\circ} \mathrm{C}$ and (iii) $1400{ }^{\circ} \mathrm{C}$ to verify the accuracy of thermal-to-electric energy conversion in the TPV system model. TPV Model-2 and TPV Model-3 are simulations of possible future applications of TPV systems.

\section{TPV system model}

The relation between a peak spectral wavelength and the temperature of the surface emitting that radiation is given by Wein's Displacement Law;

$\lambda_{\text {Peak }} \mathrm{T}=2898(\mu \mathrm{m} \mathrm{K})$

where $\lambda$ is the wavelength in $\mu \mathrm{m}$ and $\mathrm{T}$ is the temperature in Kelvin.

TPV cell bandgap varies with wavelength [19]:

$\mathrm{E}=1.24 / \lambda(\mathrm{eV})$

where $\mathrm{E}$ is the energy/band gap in $\mathrm{eV}$ and $\lambda$ is the wavelength in $\mu \mathrm{m}$. The relationship in Eqs. (1) and (2) are summarized in Fig. 3. The TPV operating temperature at $1000{ }^{\circ} \mathrm{C}$, for example, requires a TPV cell bandgap approximately $0.55 \mathrm{eV}$ that has an emission wavelength of $2.25 \mu \mathrm{m}$.

For an ideal TPV system where emissivity, $\varepsilon=1$ and reflectivity $\rho=0$, the maximum power output would be [18]:

$\mathrm{P}_{\max }=\frac{15}{\pi^{4}} \mathrm{~A}_{\text {cell }} \sigma \mathrm{T}_{\mathrm{Em}}^{4} \mathrm{~s}_{\mathrm{bg}}\left[\mathrm{s}_{\mathrm{bg}}^{2}+2 \mathrm{~s}_{\mathrm{bg}}+2\right] \mathrm{e}^{-\mathrm{s}}$

where $A_{\text {cell }}$ is the surface area of TPV cell, $\sigma$ is Stefan-Boltzmann constant, $\mathrm{T}_{\mathrm{Em}}$ is emitter temperature, $\mathrm{s}_{\mathrm{bg}}$ is an integral constant given by [15];

$s_{b g}=\frac{E_{b g}}{k T_{E m}}$

where $\mathrm{E}_{\mathrm{bg}}$ is the band-gap energy, $\mathrm{k}$ is Boltzmann constant.

Eq. (3) shows that the power output from TPV energy conversion depends upon emitter temperature for a given combination of TPV surface area, emitter emissivity and reflectivity.

Conversion efficiency is given by [15];

$\eta_{\max }=\frac{\mathrm{s}_{\mathrm{bg}}\left[\mathrm{s}_{\mathrm{bg}}^{2}+2 \mathrm{~s}_{\mathrm{bg}}+2\right]}{\left[\mathrm{s}_{\mathrm{bg}}^{3}+3 \mathrm{~s}_{\mathrm{bg}}^{2}+6 \mathrm{~s}_{\mathrm{bg}}+6\right]}$

Unutilized photon energy increases TPV cell temperature, reducing conversion efficiency. The operating temperature range for optimal TPV cell efficiency requires a specific $s_{\mathrm{bg}}$ value, so by selecting a material that provides an appropriate emitted radiation spectrum, optimal 


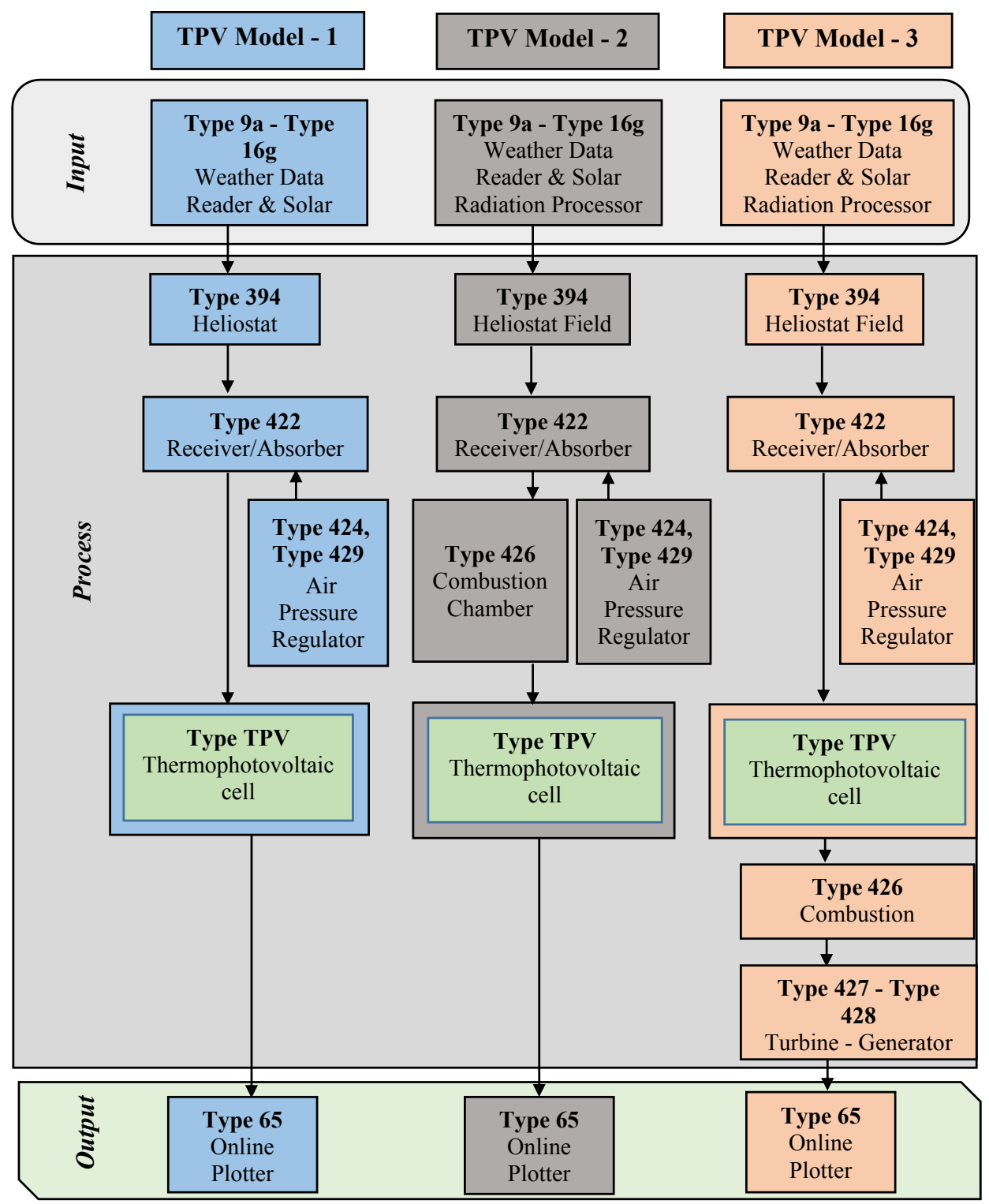

Fig. 2. TRNSYS models of TPV systems simulated.

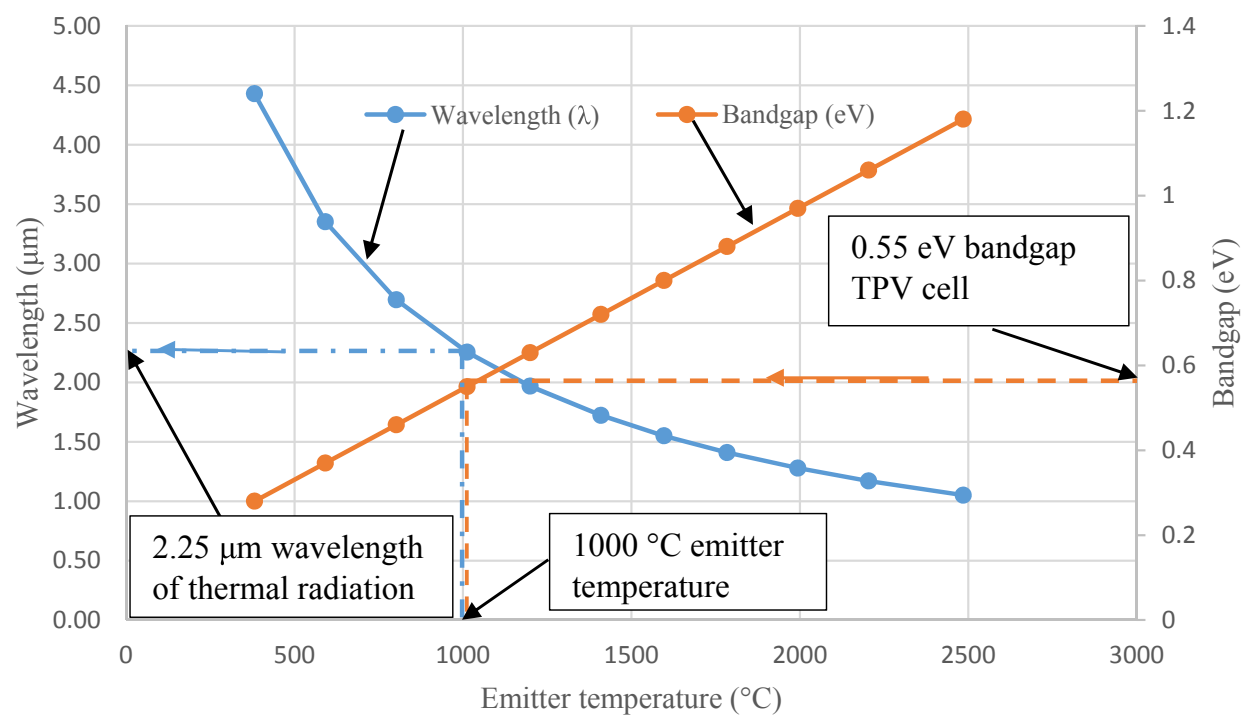

Fig. 3. Relationship of bandgap, wavelength and temperature. 


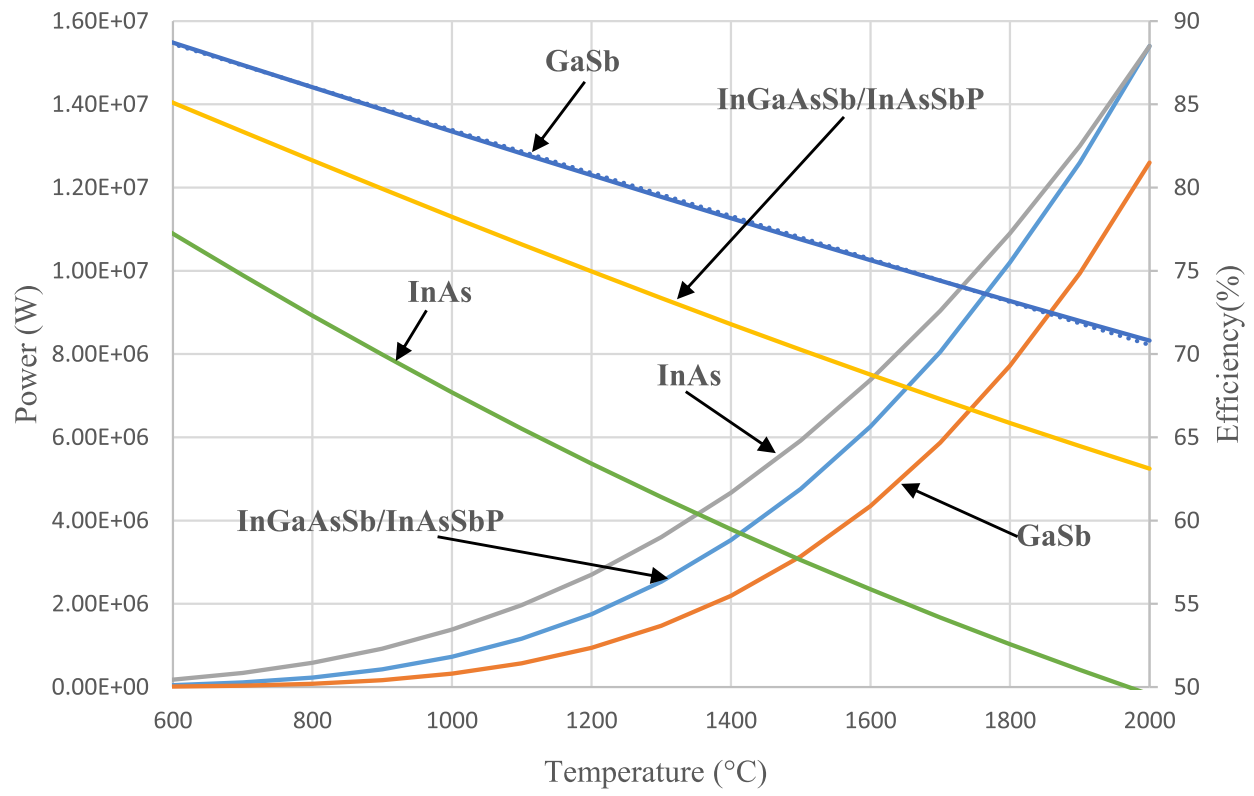

Fig. 4. Variation of TPV cell power output and conversion efficiency with temperature change.

TPV system efficiency may be achieved [18].

\subsection{TPV cell parameter analysis}

For GaSb $\left(E_{g}=0.72 \mathrm{eV}\right)$, InGaAsSb/InAsSbP $\left(E_{g}=0.55 \mathrm{eV}\right)$ and InAs $\left(E_{g}=0.36 \mathrm{eV}\right)$ TPV cells, Fig. 4 illustrates the variation of output power and conversion efficiency with the function of TPV cell temperature $\mathrm{T}_{\text {cell }}$ and emitter temperature $\mathrm{T}_{\mathrm{E}}$. High conversion efficiency does not ensure large power output, as efficiency depends on the dimensionless bandgap $s_{\mathrm{bg}}$ for an ideal TPV system where emissivity and reflectivity are constant. As $s_{\mathrm{bg}}$ is inversely related to temperature as shown in Eq. (4), conversion efficiency decreases for all types of TPV cells as temperature increases, as can be seen in Fig. 4.

As can be seen in Fig. 4, power output increases for all TPV cell types as emitter temperatures are increased. High integral constant (i.e. $s_{\mathrm{bg}}$ in Eq. (4)) values correspond to low emitter temperatures that produce significantly lower electric power output. In contrast a low $s_{\mathrm{bg}}$ produces a higher electric power output with comparatively low conversion efficiency. An optimized $s_{\mathrm{bg}}$ value indicates the best emitter temperature range for optimal efficiency of a specific TPV cell.

In previous research, a maximum conversion efficiency ( $\eta_{\text {Max }}$ ) of $78 \%$ was found for a GaSb TPV cells when $\mathrm{s}_{\mathrm{bg}} \approx 5$ [18]. This study also found that for InGaAsSb/InAsSbP and InAs TPV cells, when the $s_{\mathrm{bg}} \approx 5$ could produce approximately $78 \%$ of thermal to electric conversion efficiency, although the power output varies depending on the bandgap of the TPV cell, as shown in Table 1.

Variation of the integral constant $\left(\mathrm{s}_{\mathrm{bg}}\right)$ has a significant effect on power output as it decreases when $s_{\mathrm{bg}}$ increases. Efficiency however, increases as the $s_{\mathrm{bg}}$ increases. For the GaSb, InGaAsSb/InAsSbP and InAs TPV cells, emitter temperatures with approximately $78 \%$ conversion efficiency at $\mathrm{s}_{\mathrm{bg}} \approx 5$ are found to be $1400{ }^{\circ} \mathrm{C}, 1000{ }^{\circ} \mathrm{C}$ and $550{ }^{\circ} \mathrm{C}$ respectively as shown in Fig. 5 .

Table 1

Variation of parameters of different TPV cell at $s_{\mathrm{bg}} \approx 5$ [18].

\begin{tabular}{llll}
\hline TPV cell & Band-Gap (eV) & Efficiency (\%) & Power Output(W) \\
\hline GaSb & 0.72 & 78.2 & $2,190,000$ \\
InGaAsSb/InAsSbP & 0.55 & 78.2 & 728,000 \\
InAs & 0.36 & 78.5 & 123,000 \\
\hline
\end{tabular}

\subsection{TPV model validation}

Hosani et al. [33] examined power output of a Germanium (Ge) TPV cell $\left(\mathrm{E}_{\mathrm{g}}=0.76 \mathrm{eV}\right)$ with a tungsten photonic crystal emitter material with a 0.195 emissivity. It was found that the conversion efficiency was $11.9 \%$ at an emitter temperature of approximately $1000{ }^{\circ} \mathrm{C}$. The model proposed in this work calculated the TPV conversion efficiency to be of $9.3 \%$ when applied emitter emissivity of 0.195 at $1000{ }^{\circ} \mathrm{C}$ as it shown in Table 2.

For a Ga based TPV cell, TPV conversion efficiency has been found to reduce by less than $1 \%$ for every $20^{\circ} \mathrm{C}$ [34]. TPV efficiency decreased linearly for the temperature range $30-130{ }^{\circ} \mathrm{C}$. Although this work also found a linear decrement of TPV conversion efficiency, the rate of temperature change was not as sharp as $1 \%$ per $20{ }^{\circ} \mathrm{C}$. However, in a broader temperature range as shown in Fig. 4 illustrated significant change of efficiency as the temperature rises, where conversion efficiency dropped $0.3 \%$ per $20{ }^{\circ} \mathrm{C}$ for Ga based TPV cell whereas, a $0.5 \%$ efficiency drop was observed per $20{ }^{\circ} \mathrm{C}$ for an InAs TPV cell.

Nam et al. [35] showed that the power output of InGaAsSb is greater than GaSb TPV cell at the same temperature. The model in this study also found that at the same temperature InGaAsSb TPV cell with $0.55 \mathrm{eV}$ of band-gap produced higher power output than GaSb TPV cell with $0.72 \mathrm{eV}$ band-gap. The normalized power output from derived model is compared with those experimental results [35] as shown in Fig. 6. The modelled power is overestimated compared with the experimental results as it is derived from ideal case TPV characteristics that excluded thermal energy losses.

In this work, the output power profile of the modelled TPV system is compared with the simulation results and experimental results produced by Schlenker et al. [36]. As shown in Fig. 7, two graphs have been obtained from the modelled TPV system with (i) 0.1 emissivity [36] and (ii) 0.195 emissivity from previous studies [33]. In case of 0.1 emittance, presented TPV model produced an underestimated power output in comparison with the experimental result. A maximum of $40 \%$ deviation is observed for the output power at a temperature of $700{ }^{\circ} \mathrm{C}$. For modelled results with 0.195 emissivity, a maximum deviation of $18 \%$ is found from TPV simulations. 


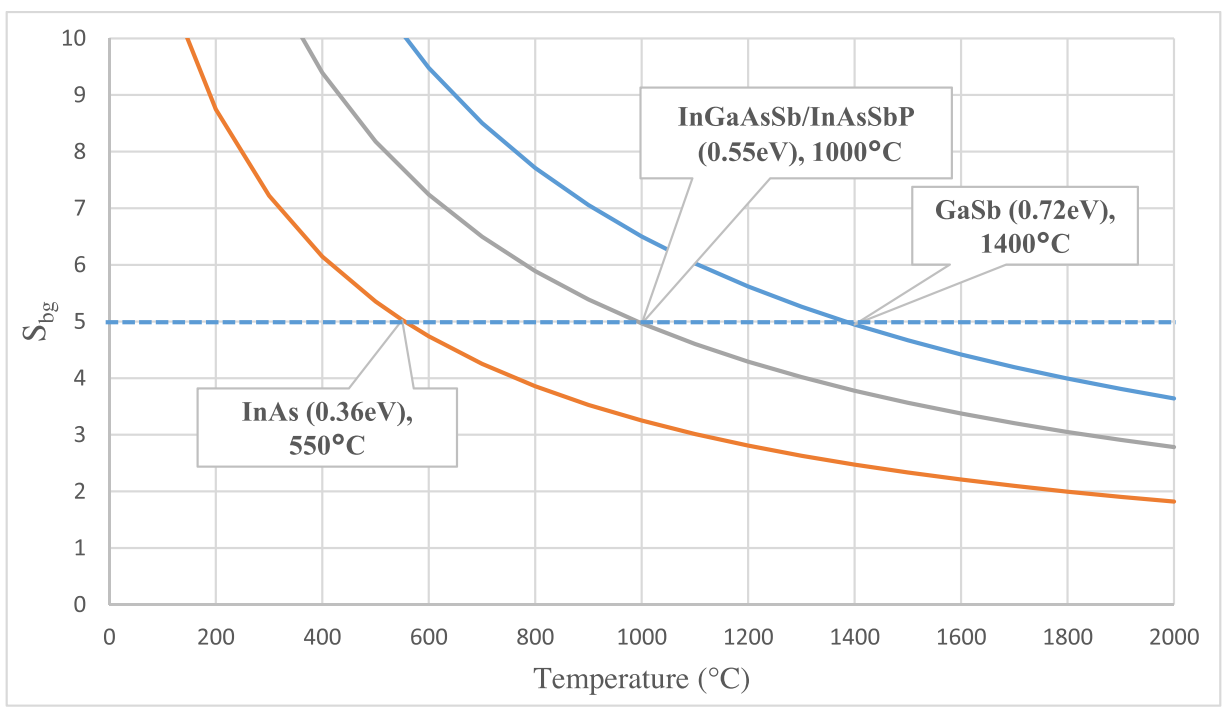

Fig. 5. Temperature variation with the integral constant ( $s_{g}$ ) for (i) GaSb, (ii) InGaAsSb/InAsSbP and (iii) InAs TPV cells.

Table 2

Comparison of modelled and experimental TPV cell performance [33].

\begin{tabular}{lll}
\hline System parameters & Experimental result & Modelled result \\
\hline Emissivity & 0.195 & 0.195 \\
Pmax $\left(\mathrm{W} / \mathrm{cm}^{2}\right)$ & 0.34 & 4.5 \\
$\eta(\%)$ & 11.9 & 9.3 \\
\hline
\end{tabular}

\section{TPV system performance}

\subsection{Model implementation of "Type TPV" in TRNSYS}

Eqs. (1)-(3) are used for a TPV system algorithm in a 'TPV' equation box in TRNSYS that is connected to a solar central receiver component. The algorithm processed input solar energy to generate electricity in simulation TPV Model-1. For hybrid TPV operation in TPV Model-2, the TPV algorithm is connected with a biomass combustion system that simulates to maintain the required process temperature when solar energy is inadequate. TPV Model-3 simulates a conceptual hybrid power plant configuration where a TPV system could be retrofitted to an existing hybrid solar central receiver-biomass power plant. The Direct Normal Irradiance (DNI) input data for all presented models is set to be $1800 \mathrm{kWh} / \mathrm{m}^{2}$ for an average eight hours in a typical summer day. The simulated solar field consists of 390 to 670 two axis tracking heliostat mirrors with a $120 \mathrm{~m}^{2}$ surface area, depending on required process temperatures of Model-1, Model-2 and Model-3 [37].

\subsection{TPV Model-1 simulation}

The TRNSYS deck file for standalone TPV operation (i.e. Model-1) is presented in Fig. 8. The electric power output of InGaAsSb/InAsSbP TPV cell is first simulated at $1000{ }^{\circ} \mathrm{C}$ temperature using 390 heliostat mirrors. The absorber area and a TPV cell surface area are set to $25 \mathrm{~m}^{2}$ [38]. Simulated peak electric power output for an ideal case TPV cell at $1000{ }^{\circ} \mathrm{C}$ is found to be $0.73 \mathrm{MW}$, illustrated in Fig. 9. As shown in Fig. 4, modelled TPV output power shows a linear relationship to temperature. In the ideal case, the thermal energy to electricity conversion efficiency is simulated to be approximately $78 \%$ as Fig. 4 illustrated, with a simulated corresponding dimensionless TPV cell band gap; $s_{\mathrm{bg}} \approx 5$ (as also analysed in Fig. 5).

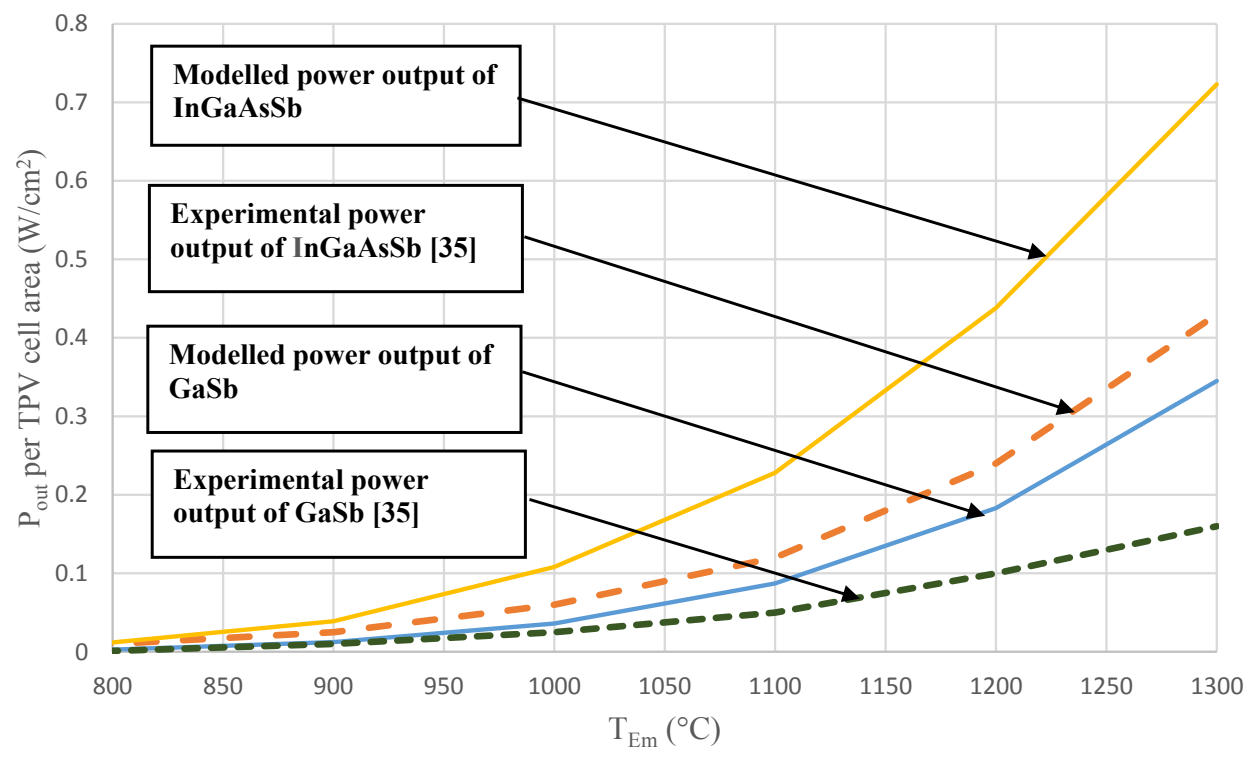

Fig. 6. Normalized modelled TPV output vs experimental results. 


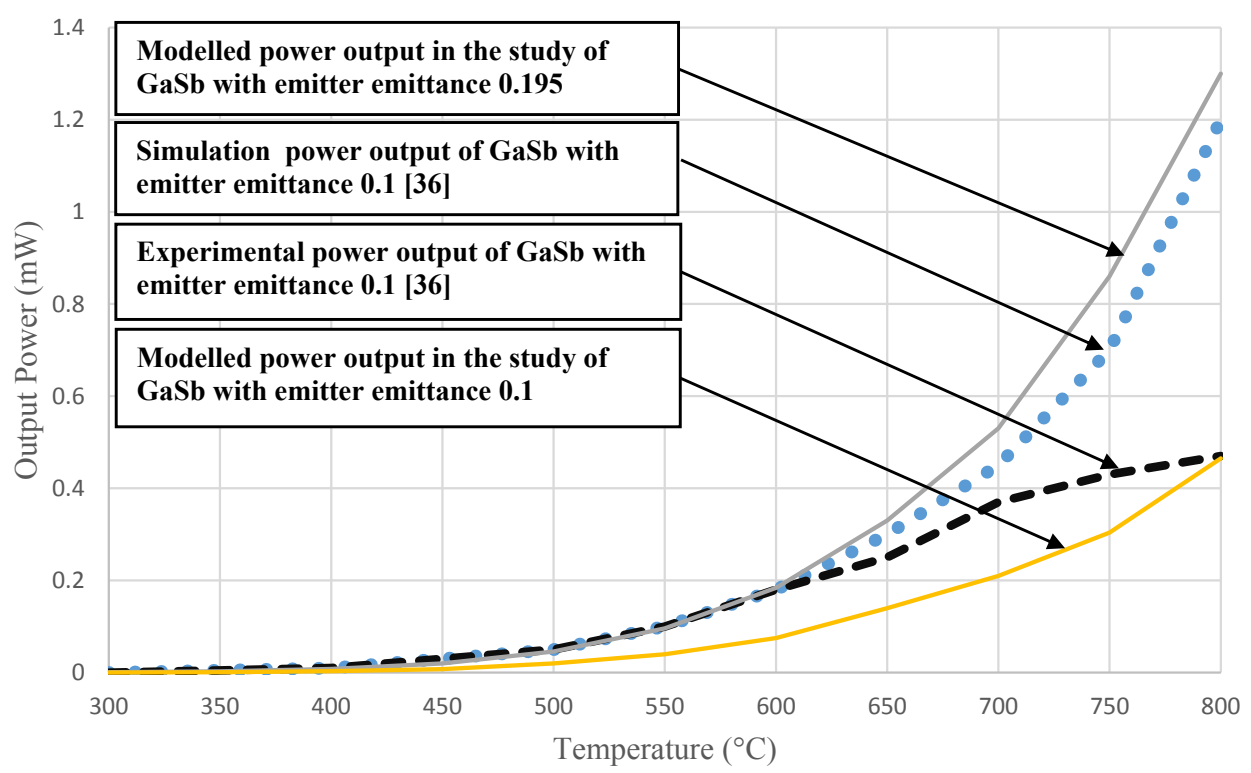

Fig. 7. Comparison of modelled TPV output with TPVexpt simulation result, and experimental measurement.

To obtain a process temperature of $1200{ }^{\circ} \mathrm{C}$, the simulated solar field requires 520 heliostats. The simulated peak output power is found to be 1.75 MW as shown in Fig. 10, significantly above that in Fig. 9. However, calculated conversion efficiency is approximately $75 \%$, which is $3 \%$ less than the previous result. The $s_{\mathrm{bg}}$ is found to be 4.3 . The simulation results can be compared with TPV analysis as illustrated in Figs. 4 and 5 .

A temperature of $1400{ }^{\circ} \mathrm{C}$ is produced by a solar field consisting of 670 heliostat mirrors. As shown in Fig. 11., 3.53 MW of peak output electricity is obtained. This is the largest power output among the three stand-alone TPV systems. In contrast the calculated $72 \%$ conversion efficiency is the lowest among the three stand-alone systems with a $\mathrm{s}_{\mathrm{bg}}$ of 3.8. These simulation results comply with the TPV model analysis presented in Figs. 4 and 5.

\subsection{TPV Model-2 simulation}

Model-2 is a simulation of a solar-biomass hybrid power plant with InGaAsSb/InAsSbP TPV cell at the rated biomass combustion temperature of $1000{ }^{\circ} \mathrm{C}$. The inlet air temperature of biomass system is set to $1000^{\circ} \mathrm{C}$ in day times when biomass unit operates at minimum load. The inlet temperatures dropped to $300{ }^{\circ} \mathrm{C}$ at night when biomass systems operate at full mode. The inlet air flow rate is $75,000 \mathrm{~kg} / \mathrm{h}$, where inlet air pressure is $1500 \mathrm{kPa}$. The solar heliostat system consisting of 390 mirrors has a pressurised air receiver (TRNSYS Type 222). The TRNSYS TPV system component is connected to the biomass combustion unit to receive continuous thermal energy. This model could also be applied to a small scale hybrid solar-biomass TPV system that uses high concentration solar concentrator such as parabolic dish with a smaller biomass fired combustion system. The hybrid system deck file in TRNSYS is illustrated in Fig. 12.

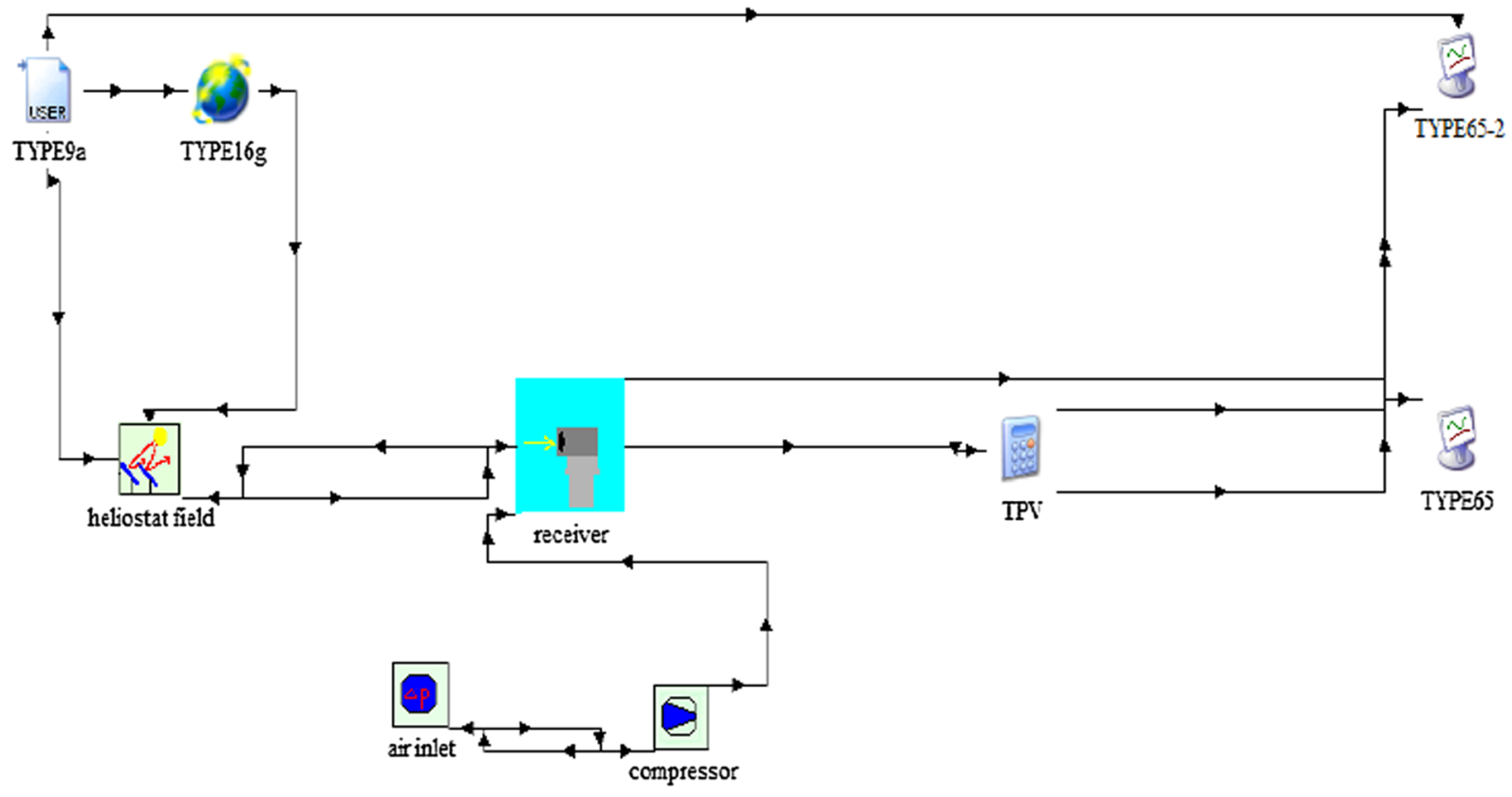

Fig. 8. TRNSYS deck file for standalone solar TPV system. 


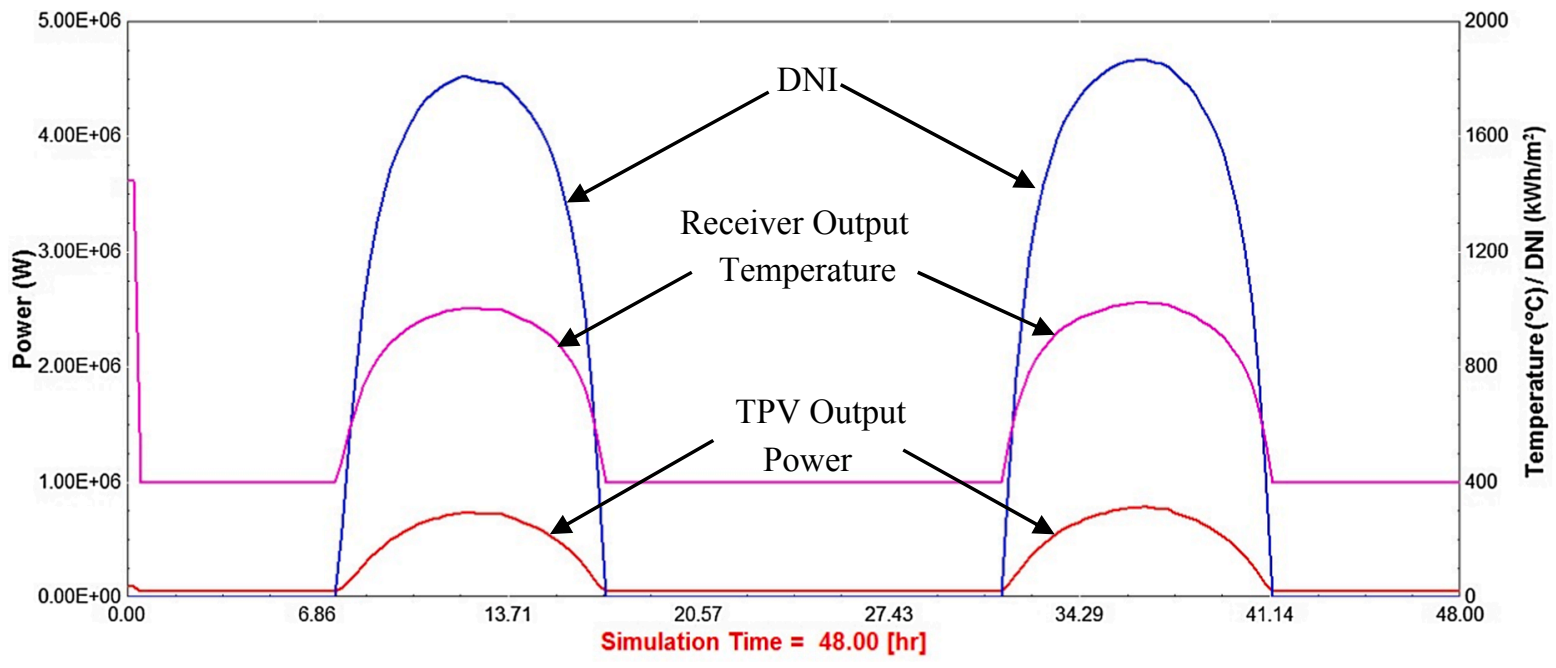

Fig. 9. TPV conversion at $1000{ }^{\circ} \mathrm{C}$ temperature.

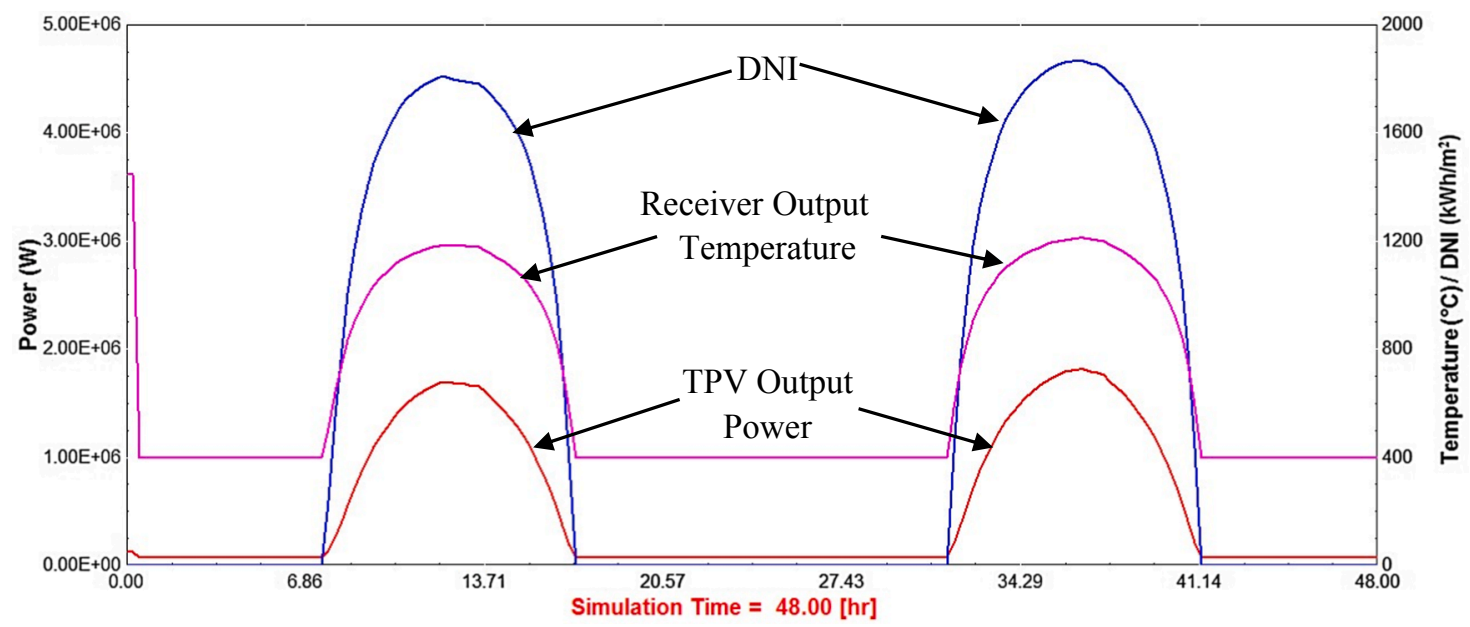

Fig. 10. TPV conversion at $1200{ }^{\circ} \mathrm{C}$ temperature.

The simulated thermal energy output and electric power obtained from a hybrid TPV system is shown in Fig. 13. The process temperature is maintained at $1000{ }^{\circ} \mathrm{C}$ by the biomass combustion system which operates in full mode when solar energy is inadequate. The biomass system operates at a minimum load during effective solar periods. The overall daily solar fraction in this plant is approximately $80 \%$. The fuel consumption of the biomass combustion system reduces linearly as the solar energy (DNI) increases. The simulated power output is $0.72 \mathrm{MW}$ for a $1000{ }^{\circ} \mathrm{C}$ emitter temperature, with a conversion efficiency of $78 \%$.

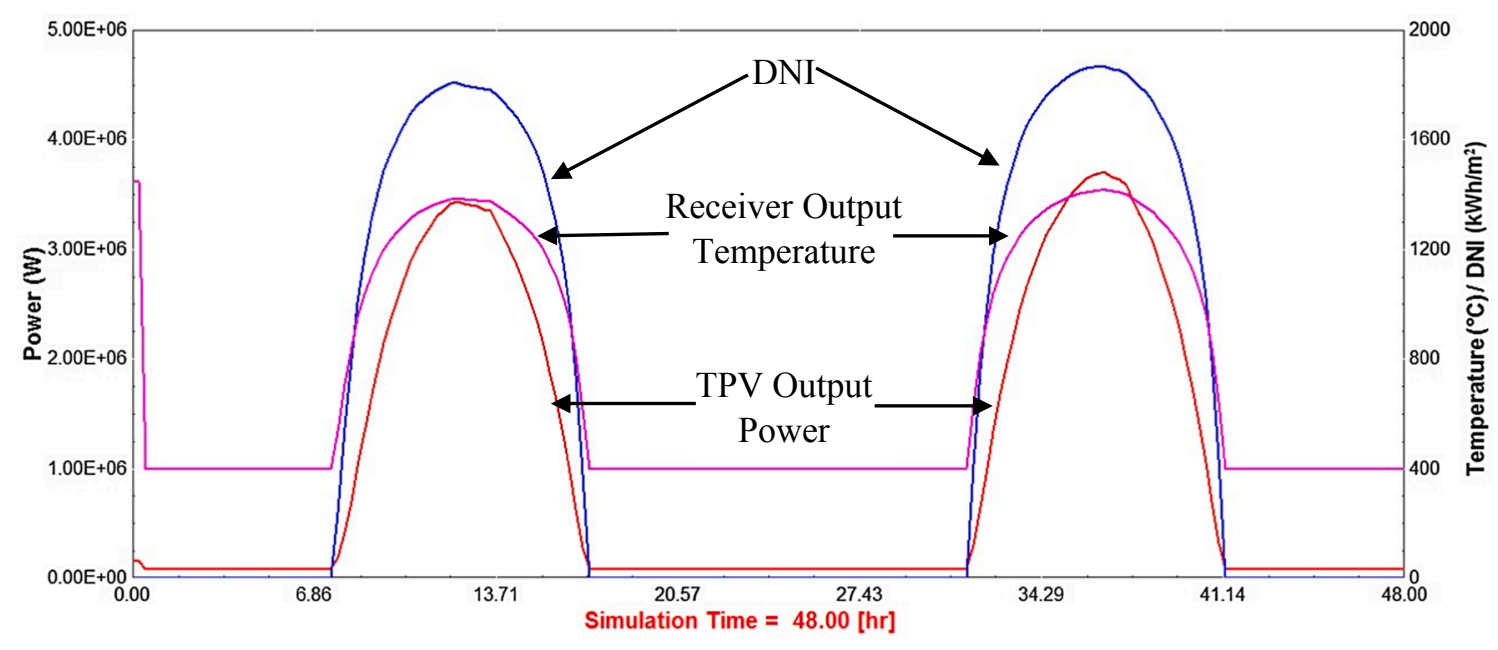

Fig. 11. TPV conversion at $1400{ }^{\circ} \mathrm{C}$ temperature. 


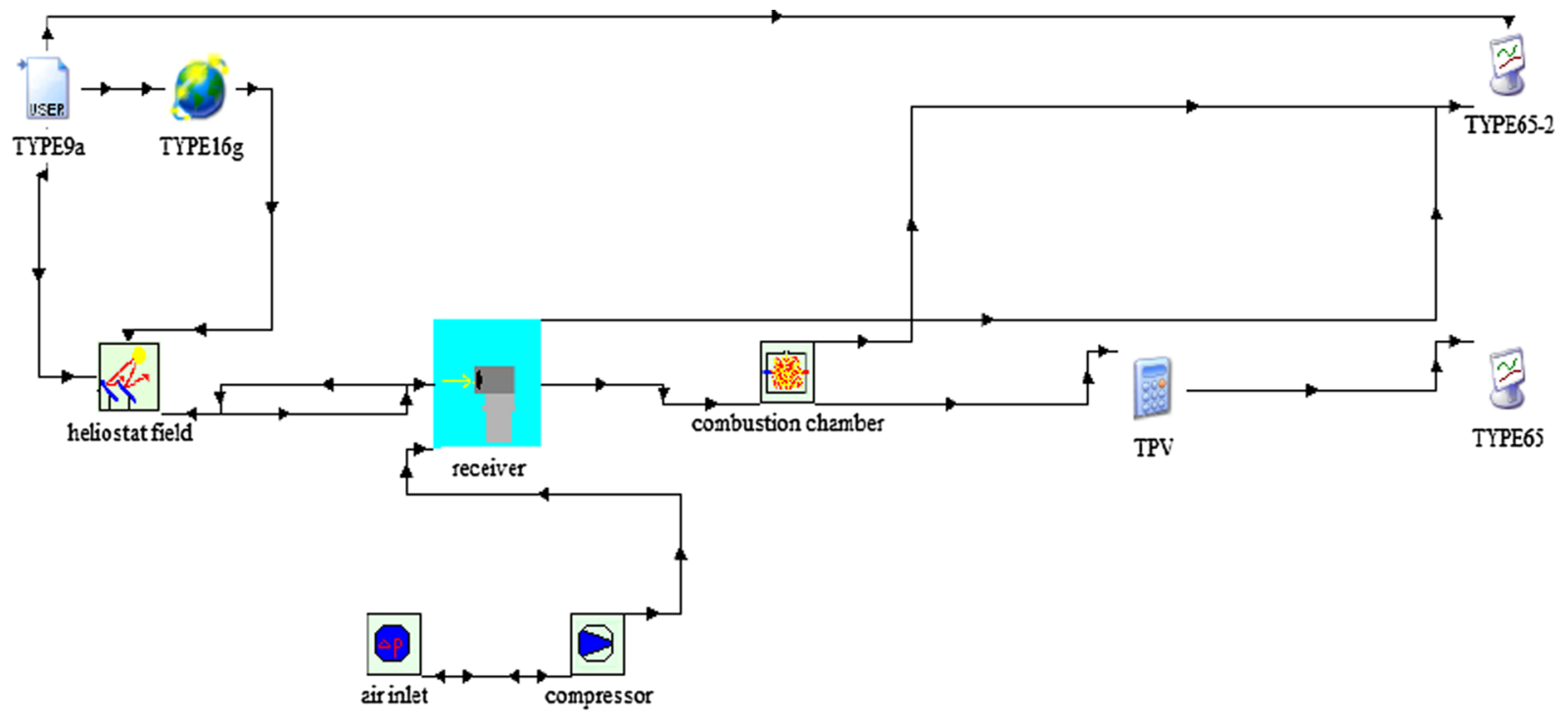

Fig. 12. TRNSYS deck file for TPV Model-2.

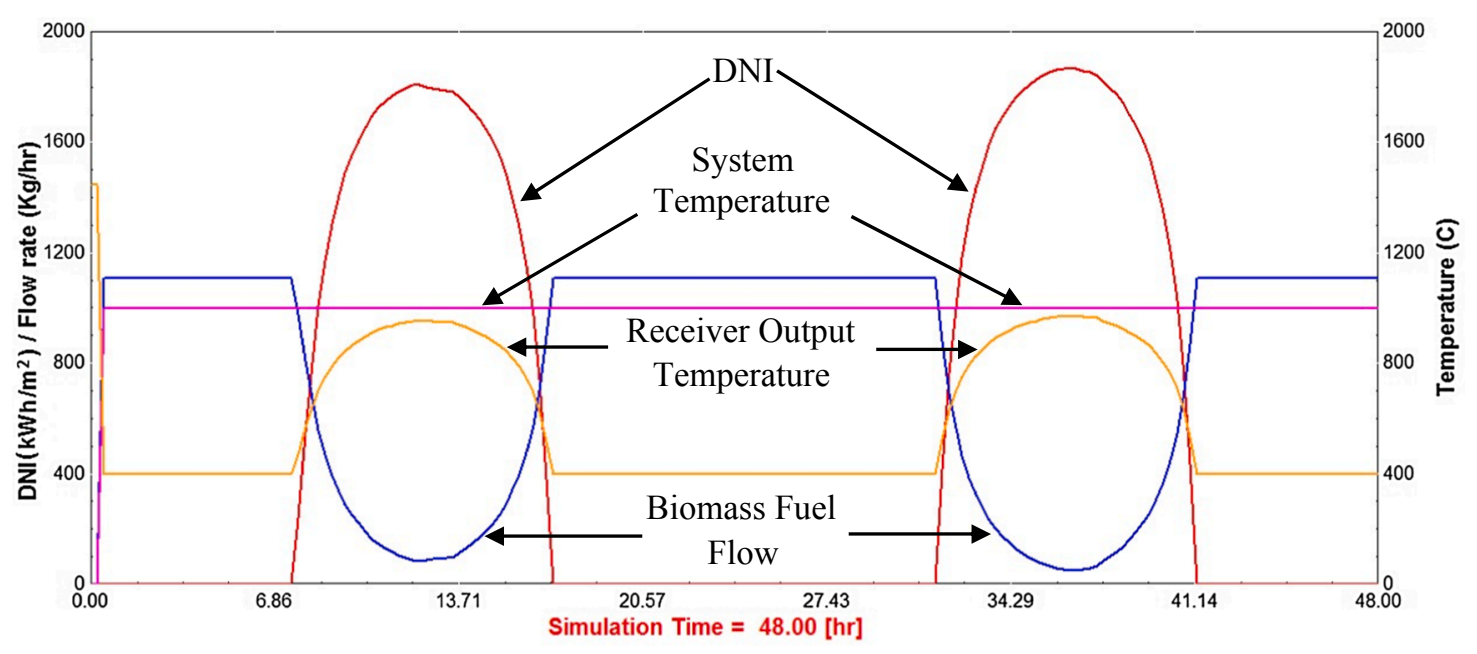

Fig. 13. Model-2 conversion at $1000{ }^{\circ} \mathrm{C}$ temperature.

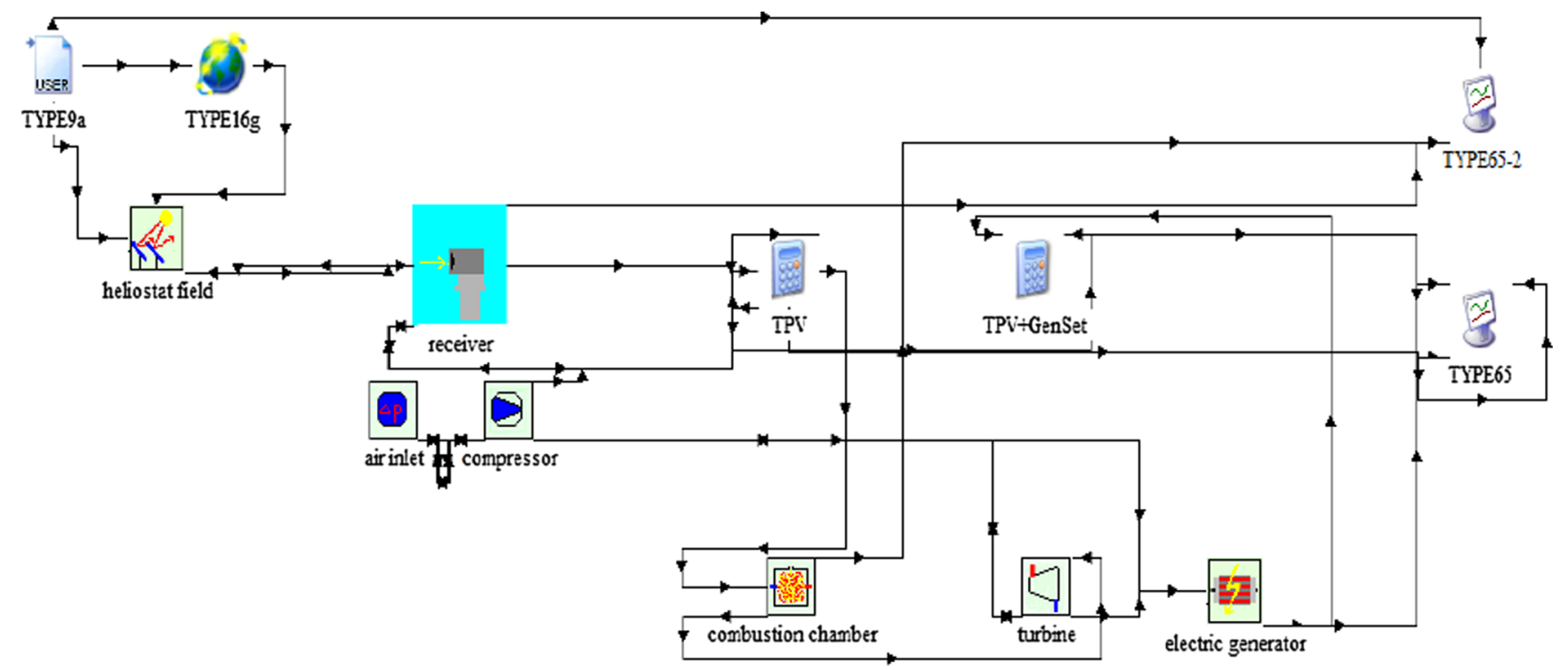

Fig. 14. TRNSYS deck file for TPV Model-3. 


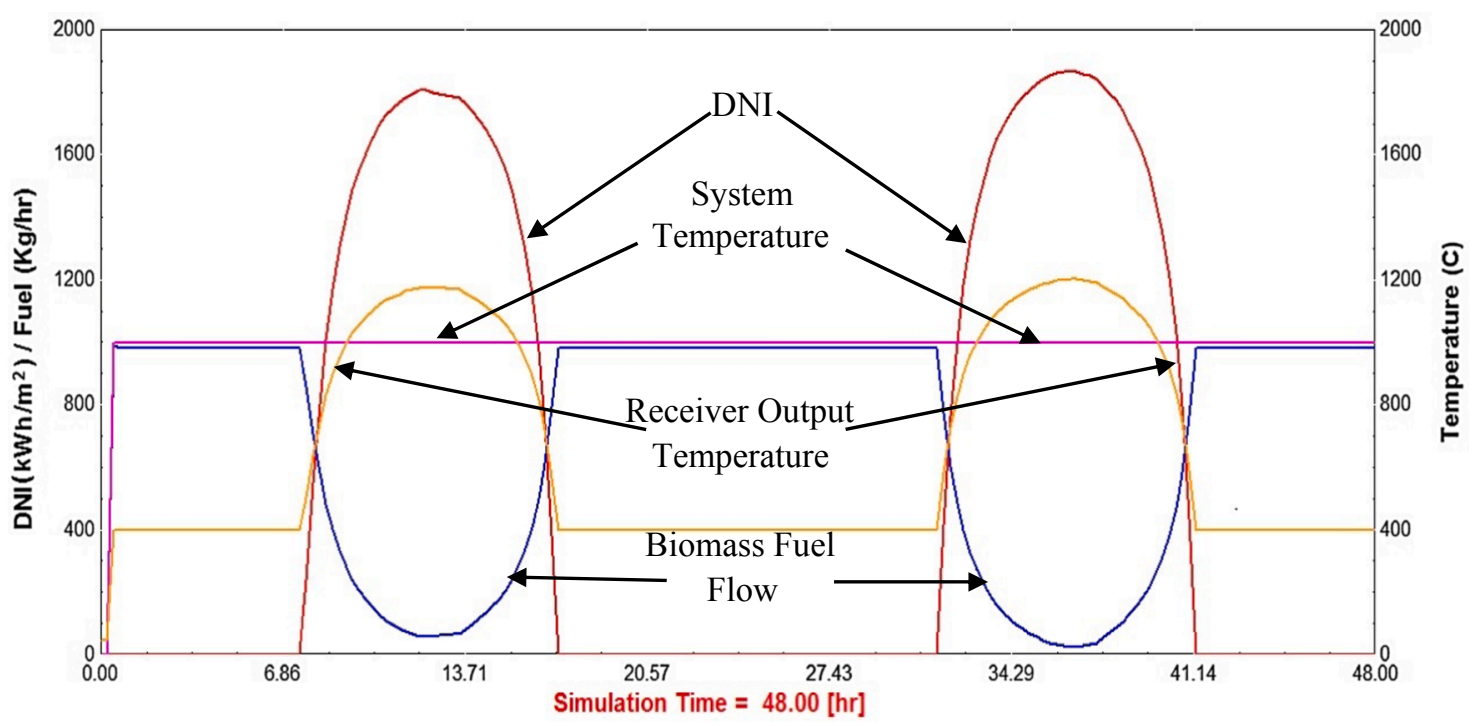

Fig. 15. Hybrid solar-biomass TPV conversion at $1000{ }^{\circ} \mathrm{C}$ temperature.

\subsection{TPV Model-3 simulation}

In Model-3 a TPV system is integrated with an existing CSP-biomass Brayton Cycle power plant. TPV cell is located in the absorber of the solar tower, thus connected to the solar receiver directly as shown in Fig. 14. The temperature gained from the solar field is absorbed primarily by the TPV cell. Thermal energy unutilized by TPV cell is then transferred to the biomass combustion system that rotates a turbine electric generator. A cumulative output power is calculated from the outputs of the TPV and Brayton cycle power generating systems.

Simulated temperature from the solar field is found to be higher than the rated combustion temperature as shown in Fig. 15. Simulated peak temperature obtained from the solar field is $1200{ }^{\circ} \mathrm{C}$ where the combustion system maintained the temperature at $1000{ }^{\circ} \mathrm{C}$ (Fig. 15). As can be seen, solar energy is dumped as there is an overproduction of thermal energy beyond the rated power block capacity.

In contrast, a reduced electric power output is observed in the simulation result when the solar energy increases as shown in Fig. 16. This reduced electric output is due to less total air mass flow produced by solar energy system and delivered into the turbine in a hybrid Brayton Cycle CSP-fuel power plant [32]. Solar thermal energy dumping, leading to a reduced electric power output could be addressed by retrofitting a TPV system in a hybrid CSP-biomass power generation system so that the additional electricity produced by a TPV system recovers a significant amount of solar energy that would otherwise be unused. This maintains the plant rated power output during the solar period, thus improving overall solar fraction of the hybrid power plant as shown in Fig. 17.

\section{Discussion and conclusion}

It is difficult to synchronize CSP power plant input temperatures and pressures to utilize optimum solar energy during effective solar periods as the temperatures of working fluids usually become higher than the rated power block input at midday. Having thermal energy exceeding power block capacity causes solar energy to be dumped. This surplus thermal energy is not easily recovered due to the cost and complexity of the power plant configuration. However, a TPV system could increase power generation capacity by utilizing the solar energy produced by solar collators at midday. Integration of a TPV system with low bandgap TPV cell (such as InGaAsSb/InAsSbP or InAs) in a hybrid CSPbiomass power plant may thus increase the solar fraction leading to improved plant economic viability. A TPV system enables a solar power plant to recover the waste heat without integrating any additional

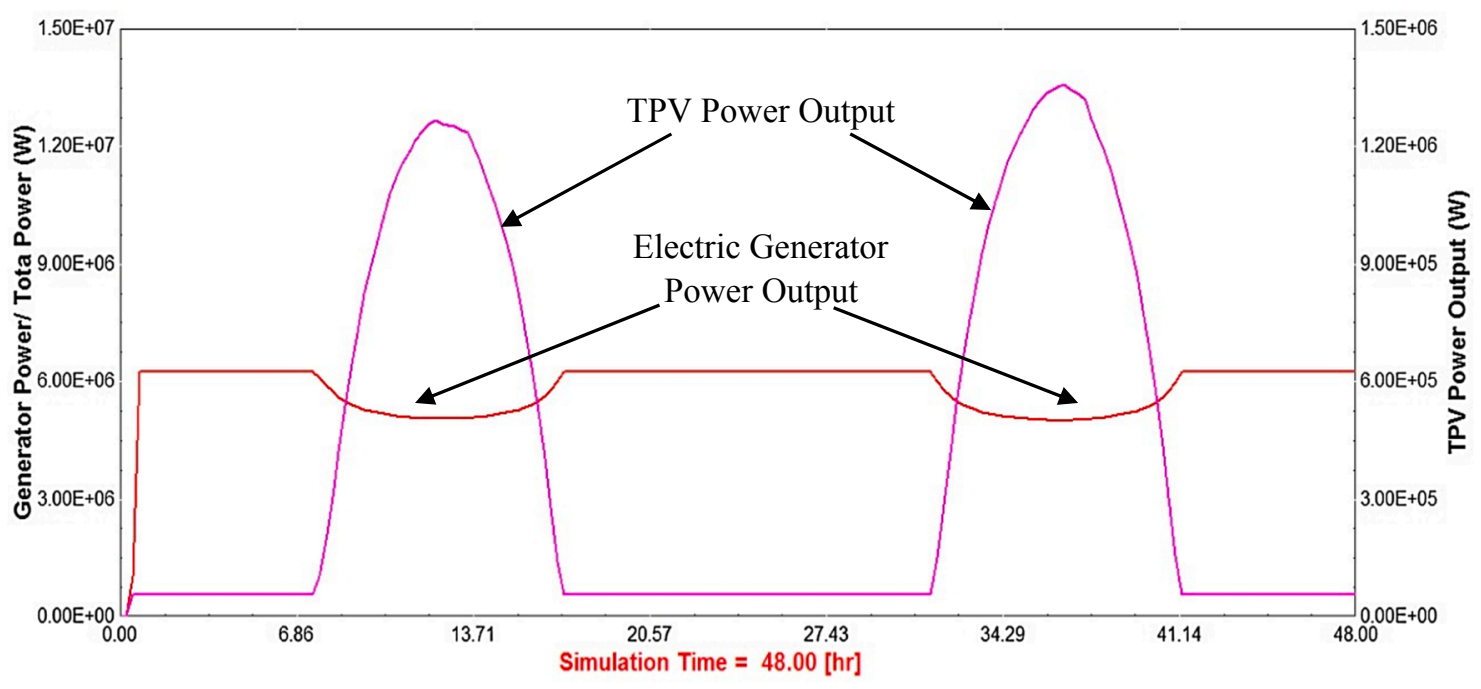

Fig. 16. Individual power output of TPV and Electric turbine generator. 


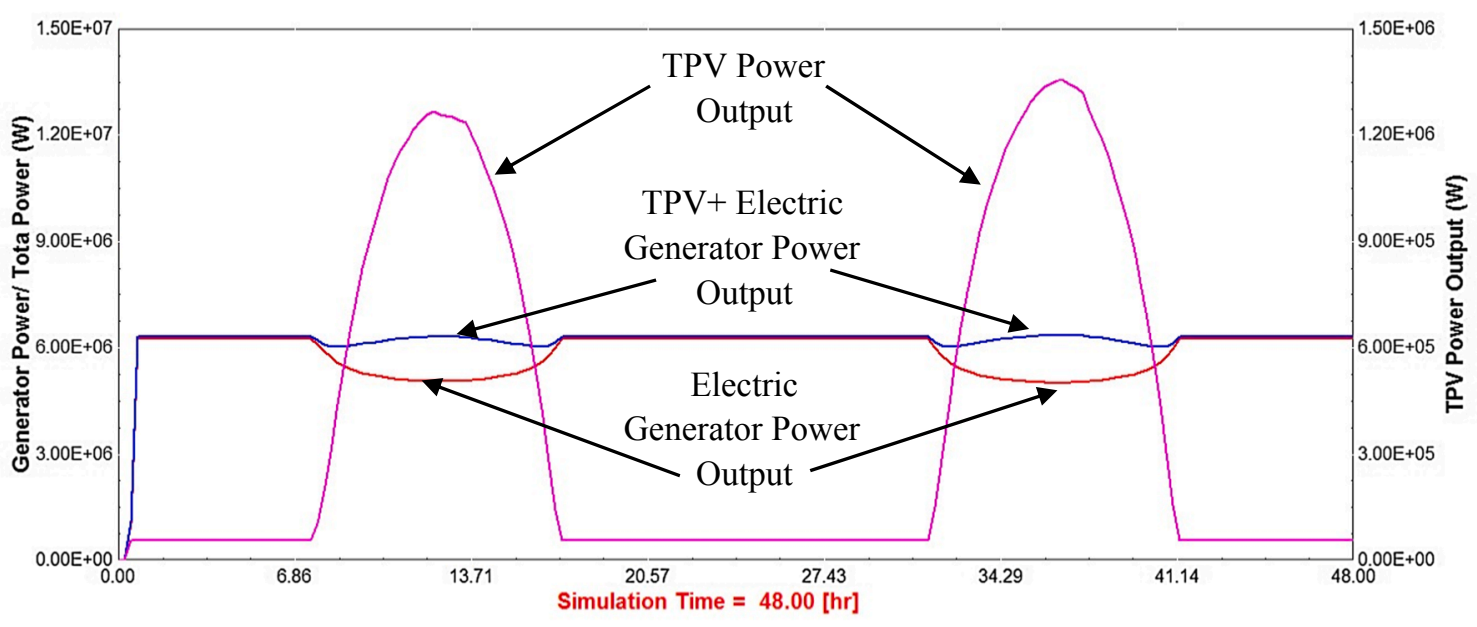

Fig. 17. Power output of hybrid solar-biomass TPV- Brayton cycle systems.

moving parts (as would be required in Rankine/Brayton cycle system) thus incurring less operating and maintenance expenditure.

Solar-biomass TPV systems differ from conventional solar-biomass Rankine/Brayton cycle power plant in their operating principles. At a medium operating temperature, it has been shown that a TPV system could be applied to a hybrid solar-biomass power plant to reduce biomass fuel consumption as well as increase the solar fraction of a CSP power plant.

\section{Declaration of Competing Interest}

The authors declared that there is no conflict of interest.

\section{Acknowledgements}

The authors appreciate the financial support provided by Technological University Dublin under the Fiosraigh research scholarships scheme. This research was supported by MaREI, the SFI Research Centre for Energy, Climate and Marine [Grant No: 121RC12302-P2].

\section{References}

[1] Datas A, Algora C. Detailed balance analysis of solar thermophotovoltaic systems made up of single junction photovoltaic cells and broadband thermal emitters. Sol Energy Mater Sol Cells 2010;94:2137-47.

[2] Daneshvar H, Prinja R, Kherani NP. Thermophotovoltaics: fundamentals, challenges and prospects. Appl Energy 2015;159:560-75.

[3] Ferrari C, Melino F, Pinelli M, Spina PR. Thermophotovoltaic energy conversion: analytical aspects, prototypes and experiences. Appl Energy 2014;113:1717-30.

[4] Bitnar B, Durisch W, Holzner R. Thermophotovoltaics on the move to applications. Appl Energy 2013;105:430-8

[5] Mustafa KF, Abdullahb S, Abdullaha MZ, Sopian K. A review of combustion-driven thermoelectric (TE) and thermophotovoltaic (TPV) power systems. Renew Sustain Energy Rev 2017;71:572-84.

[6] Medina AD. Development of solar thermophotovoltaic systems Phd Thesis Technical University of Madrid; 2011

[7] Celanovic I, Bermel P, Soljacic M. Thermophotovoltaic power conversion systems: current performance and future potential. Invited Review Article in Oyo Buturi (Jpn Soc Appl Phys) 2011;80:6.

[8] Fraas J, Minkin L, Huang HX. Design of a matched IR emitter for a portable propane fired TPV power system. JX Crystals Inc; 2014, p. 110512.

[9] Strandberg R. Theoretical efficiency limits for thermoradiative energy conversion. J Appl Phys 2015;117:055105.

[10] Zhou Z, Chen Q, Bermel P. Prospects for high-performance thermophotovoltaic conversion efficiencies exceeding the Shockley-Queisser limit. Energy Convers Manage 2015;97:63-9.

[11] Xie M. Van der Waals bilayer antimonene: a promising thermophotovoltaic cel material with 31\% energy conversion efficiency. Nano Energy 2017;38:561-8.

[12] Bermel P. Design and global optimization of high-efficiency thermophotovoltaic systems. Opt Exp 2010;18:A314-34.

[13] Liao T. Parametric characteristics of a solar thermophotovoltaic system at the maximum efficiency. Energy Convers Manage 2016;126:205-9.

[14] Chubb DL, Good BS. A combined thermophotovoltaic-thermoelectric energy converter. Sol Energy 2018;159:760-7.
[15] Wu H, Kaviany M, Kwon OC. Thermophotovoltaic power conversion using a superadiabatic radiant burner. Appl Energy 2018;209:392-9.

[16] Lou Y. Enhanced thermal radiation conversion in a GaSb/GaInAsSb tandem thermophotovoltaic cell. Sol Energy Mater Sol Cells 2017;172:124-32.

[17] Fraas LM. Low-cost solar electric power. Springer; 2014. (2016 Addendum).

[18] Chubb DL. Fundamentals of thermophotovoltaic energy conversion. 1st ed. Elsevier B.V; 2007. ISBN: 978-0-444-52721-9.

[19] Hussain CMI, Norton B, Duffy A, Oubaha M. Hybrid Solar thermophotovoltaicbiomass/gas power generation system with a spectrally matched emitter for lower operating temperature. 12th conference on sustainable development of energy, water and environment systems, Dubrovnik, October 4-8. 2017.

[20] Bauer T. Thermophotovoltaics: basic principles and critical aspects of system design green energy and technology. Springer [ISSN 18653529].

[21] Davis G. Hybrid thermophotovoltaic power systems. California energy commission consultant report 2002; P500-02-048F.

[22] Krier A, Yin M, Marshall ARJ, Krier SE. Low bandgap InAs-base thermophotovoltaic cells for heat-electricity conversion. J Electron Mater 2016;45:1-5.

[23] Hussain CMI, Norton B, Duffy A. Technological assessment of different solar-biomass systems for hybrid power generation in Europe. Renew Sustain Energy Rev 2016;68:1115-29.

[24] TRNSYS 17 Solar energy laboratory. University of Wisconsin-Madison 2012, p. $1-29$.

[25] Massaguer E, Massaguer A, Montoro L, Gonzalez JR. Development and validation of a new TRNSYS type for the simulation of thermoelectric generators. Appl Energy 2014;134:65-74.

[26] Kuznik F, Virgone J, Johannes K. Development and validation of a new TRNSYS type for the simulation of external building walls containing PCM. Energy Build 2010;42:1004-9.

[27] Fernandes MS, Gaspar AR, Costa VA, Costa JJ, Brites G. Optimization of a therma energy storage system provided with an adsorption module - a GenOpt application in a TRNSYS/MATLAB model. Energy Convers Manage 2018;162:90-7.

[28] Bava F, Furbo S. Development and validation of a detailed TRNSYS-Matlab model for large solar collector fields for district heating applications. Energy 2017; 135:698-708.

[29] Biencinto M, Gonzalez L, Valenzuela L. A quasi-dynamic simulation model for direct steam generation in parabolic troughs using TRNSYS. Appl Energy 2016;161:133-42.

[30] Shrivastava RL, Kumar V, Untawale SP. Modeling and simulation of solar water heater: a TRNSYS perspective. Renew Sustain Energy Rev 2017;67:126-43.

[31] Sweet ML, McLeskey JT. Numerical simulation of underground Seasonal Solar Thermal Energy Storage (SSTES) for a single family dwelling using TRNSYS. Sol Energy 2012;86:289-300.

[32] Zentrum D. A TRNSYS model library for solar thermal electric components (STEC) reference manual. Components; 2006, p. 1-53.

[33] Al Hosani M, Emziane M. Modeling and simulation of a thermophotovoltaic system with NaF heat storage. Energy Proc 2013;42:726-34.

[34] Kovacs A, Janhunen P. Thermo-photovoltaic spacecraft electricity generation. Astrophys Space Sci Trans 2010;6:19-26.

[35] Nam Y, Lenert A, Yeng YX, Bermel P, Solja M, Wang EN. Solar thermophotovoltaic energy conversion systems with tanltalum photonic crystal absorbers and emitters. The 17th international conference on solid-state sensors, actuators and microsystems, vol. 116. 2013. p. 1372-5.

[36] Schlenker E, Zhiguang Z, Peter B. Thermophotovoltaic system simulation with realistic experimental considerations. SURF Final Report; 2015.

[37] Farges O, Bézian JJ, El Hafi M. Global optimization of solar power tower systems using a Monte Carlo algorithm: application to a redesign of the PS10 solar therma power plant. Renew Energy 2018;119:345-53.

[38] Hussain Choudhury Mohammad Iftekhar, Duffy Aidan, Norton Brian. Economic appraisal of hybrid solar-biomass thermophotovoltaic power generation. Proc Instit Civ Eng - Energy 2019;172(4):162-8https://www.icevirtuallibrary.com/doi/10. 1680/jener.19.00023https://doi.org/10.1680/jener.19.00023. 